\title{
The relationship between involvement, destination emotions and place attachment in the Porto wine cellars
}

\begin{abstract}
Purpose - To measure the role of involvement, destination emotions and place attachment in the behavioural intentions of wine tourists when visiting the Porto wine cellars.

Design/methodology/approach - Interceptive survey with wine tourists during their visits in four Porto wine cellars. A convenience sample of 918 international visitants was obtained. A SEM using PLS analysis was used to test the hypothesis and the validity of the constructs and model.

Findings - The results indicated that wine tourists' personal involvement and their wine involvement have a significant and direct influence on destination emotions and place attachment in the Porto wine cellars during the visits that determines their future behavioral intentions.

Research limitations - The generalisability of the results may be limited due to sample and data collection method. Future research applying the structural model in other wine tourism destinations will help to establish the generalizability and consistency of the model.

Practical implications - There is a growing potential for researchers and managers to achieve benefits from the proposed model that will support the efforts for wine tourism theory and practice, such as strategies of positioning branding, and formulation sharper marketing strategies.

Originality/value - This is the first study demonstrating the combined use of personal and wine involvement on destination emotions along with place attachment in a wine tourist behaviour context. This approach extends the scope into a wine tourism context because the combination of these three constructs has never been held in the wine tourism destinations area. Keywords - Involvement, destination emotions, place attachment, behavioural intentions, wine tourist, Porto wine cellars, PLS

Paper type - Research paper
\end{abstract}

\section{Introduction}

Wine tourist behaviour represents a very important study domain, because understanding his behaviour is a complex process and stimulus is the key and the engine of the behaviour, particularly in the wine tourism. Yuan et al. (2006) argue that understanding the wine consumer behaviour is crucial and can bring marketing benefits. In light of this, the wine tourism development has been increasingly international, and the need to better understand the nature of the wine tourist has been a major plus theme in literature (Brown \& Getz, 2005).

Both involvement and emotions are crucial constructs for consumer behaviour (Soscia, 2013). Our previous research (Santos, Ramos \& Almeida, 2014) suggested that these constructs play a fundamental role and impact on behavioural tourists' intentions, including leisure, marketing and tourism fields, in their content analysis of the relationship between involvement and emotions. In this context wine tourists seems to seek experiences through different forms, highlighting the cultural heritage events and festivals, formal wine tastings, cellar door sales, and winery tours (Charters \& Ali-Knight, 2002) were the role of emotions and involvement are critical. The perceived benefits that tourists appreciate at destinations will affect behavioural intentions. (Liang, Illum \& Cole, 2008). In this way it is vital to understand how some attributes (valued in wine tourism) reflect the intentions of the wine tourist in order to engage in future behaviours ( $\underline{\mathrm{Sparks}}$, 
2007). There is also a gap in the role of motivational forces that drive wine tourists to consumption behaviour (Ravenscroft \& van Westering, 2001, Bruwer \& Reilly, 2006, Charters \& Ali-Knight, 2002; Getz \& Brown (2006); Hall et al. (2000). To Charters and Ali-Knight (2002) there has been little research that addressed the profile of the wine tourists, as well as their intentions. Therefore it is fundamental to have a systematic approach and a theoretically oriented development, testing the probability of visiting (and therefore re-visiting and recommending) a wine region, producer or activity (Sparks, 2007).

The aim of this study is to determine if the personal involvement, wine product involvement, destination emotions and place attachment are the most appropriate constructs to analyze and measure the wine tourist behavioural intentions when visiting the Porto wine cellars. After the literature review, the hypotheses are presented and then the methodology, data collection, and results are described and discussed. Finally, this paper presents the findings, research limitations and practical implications and suggestions for future research.

\section{Literature review and research hypotheses}

Involvement lead to favourable emotions which in turn will have a positive influence on behavioural intentions, which strengthens the importance of consumer involvement in marketing the hedonic service (Hightower, Brandy \& Baker, 2002). Emotions can play different roles (cause, mediation, effect, consequence and moderation) depending on the prior level of involvement (Bagozzi, Gopinath \& Nyer, 1999). Therefore the relationship between involvement and emotions plays a crucial role in explaining consumer behaviour (Soscia, 2013). In this line, Yeh (2013, p. 215) considers that involvement in tourism encompasses consumer attitudes in a long term, according to the activities, and the consumer behaviour is influenced by their attitudes over time. The direct effect of involvement on emotions needs still needs to be fully confirmed. Only a few studies have yet empirically explored the influence of food and wine involvement on emotional attitude such as Sparks (2007), were involvement was proved to be a good predictor of positive emotions. Loureiro, Almeida \& Rita (2013) highlighted that atmospheric cues and involvement are important antecedents of the emotions of relaxation and pleasure. It was also found that the concept of involvement is generally discussed as an antecedent of emotions based on cognitive appraisal theory (Gao et al., 2013; Nyer, 1997). Therefore greater involvement will lead to more favourable emotions (Hightower, Brandy \& Baker, 2002).

Involvement leads to favourable emotions, which, in turn, will have a positive influence on behavioural intentions, which strengthens the importance of consumer involvement in marketing the hedonic service (Hightower, Brandy \& Baker, 2002). In addition to this, the personal involvement indicates the degree to which an individual is devoted to an activity, product, or experience (Prayag \& Ryan, 2012). Involvement is also described as the state of motivation and desire towards an activity or an associated item (Gursoy \& Gavcar, 2003). In this sense, Prebensen et al. (2013) postulated that consumers' involvement helps predict their future behaviours. Likewise, Sparks (2007) points out that involvement might directly have an impact in the behavioural intentions to get on a wine tourism vacation.

The concept of involvement is generally discussed as an antecedent of place attachment (Chiu et al., 2014; Hou, Lin \& Morais, 2005) and both have a proven relationship (Williams, Patterson \& Roggenbuck 1992). According to Mowen, Graefe \& Virden (1998) and Warzecha \& Lime (2001) the activity involvement and place attachment exhibited a positive and significant relationships with setting and experience evaluations. Hwang, Lee \& Chen (2005) and (Kyle et al., 2003) also gave more evidence that the tourists' involvement has a positive significant influence on place attachment. Therefore there's evidence exists in the literature to support that personal involvement has an antecedent of place attachment (Hou, Lin \& Morais, 2005; Hwang, Lee \& Chen 2005; Kyle et al., 2004). They combined, for the first time, the relationship between place involvement and attachment a tourism context and found that they have a positive and significant relationships. 
In this study the wine tourists' personal involvement is mainly evaluated by their role in generating destination emotions during their Porto wine cellars visits. Wine tourists' personal involvement in this study is mainly evaluated by their perspective to predict behavioural intentions to visit the Porto wine cellars. In this way, we suggest involvement as an antecedent of place attachment. Hence, given the conceptualizations and based on preceding arguments, the first three hypotheses are proposed:

\section{H1: Personal involvement has a positive and significant effect on destination emotions in the Porto wine cellars}

H2: Personal involvement has a positive and significant effect on behavioural intentions to visit Porto wine cellars

H3: Personal involvement has a positive and significant effect on place attachment in the Porto wine cellars

Wine related travel also provides a pleasure seeking activity for consumers (Bruwer \& Alant, 2009; Charters \& Ali-Knight, 2002; Famularo, Bruwer \& Li, 2010). In line with Sparks (2007), it is assumed that the wine tourism and the general involvement with wine are described as a consumer experience with hedonic high charge, and it can be expected that evaluation of the experience is involved with an emotional component, ideally through the expression of positive emotions. One of the conclusions of Sparks $(2007$, p. 10) in his study was that "the wine factors were better predictors of emotional attitude". To Ali-Knight \& Carlsen (2003, p. 7), wine is characterized as a participation in experiential marketing and that wineries should promote "extraordinary" experiences and provide "unusual events and characterized by high levels of emotional intensity and experience to wine tourists". The wine consumers' product involvement captures the emotional state about the product category, which is categorized as product enthusiasm (Barber, Ismail \& Dodd, 2008).

Wine products are seen with strong cultural connotations and these products include an emotional experience that frequently influences the consumers and stays as a lasting experience (Ferrarini et al., 2010). Wine has been pointed out as a high sector in terms of emotion generating and in that sense, the emotion generation is an important component for consumer satisfaction in wine-related products such as to anticipate future behavioural intentions (Keonig-Lewis \& Palmer, 2008; Mora \& Moscarola, 2010). The level of product involvement with wine revealed that wine consumers have generic feelings which correlate with importance and relevance with a product (Yuan et al., 2005). Given the evidence from previous research conceptualization, the fourth hypothesis is presented:

\section{H4: Wine involvement has a positive and significant effect on destination emotions in the Porto wine cellars}

The wine tourist is a consumer that is characterized by the need to get involved with both wine and the place (wine region) where the wine is produced, but no cohesive theory of the wine tourist behaviour was further postulated (Bruwer \& Alant, 2009). Also wine tourists seem to have the need to be both involved with wine and with the region where it's produced (Bruwer \& Alant, 2009). Sparks (2007) argues that is vital understand the wine tourism attributes to engage consumers intentions associate with wine tourism consumption. Therefore, it is believed that a potential consumer will have a set of beliefs about the attributes that make up the tourism experience within the wine region.

The wine tourism correlates and involves the relationship between visitor-consumer, wineries and wine region (Bruwer \& Alant, 2009). The wine tourism is currently assimilated as an experience of emotions associated with vinous producing regions and wineries (Zhang, 2011). Studies among wine tourism and wine consumption points out that wine tourism activity allows participants to be involved in an area which is linked to the wine product, maintaining overall lifestyle consistency, acquire knowledge and experience about wine as a personal special interest, interact socially with individuals adhering to similar lifestyles, and yet create long term relationships with the winery (e.g., Alant \& Bruwer, 2004; Roberts \& Sparks, 2006; Yuan et al., 2005). The results of Gross \& Brown (2008) found that wine involvement has a direct effect on place attachment. Drawing on the previous findings, the fifth hypothesis is: 
H5: Wine involvement has a positive and significant relation with place attachment in the Porto wine cellars

To Low \& Altman (1992), the place attachment is the environment setting which people are emotionally attached, and people have emotional responses to their immediate environment (Machleit \& Eroglu, 2000; Hidalgo \& Hernández, 2001; Manzo, 2003; Farber \& Hall, 2007), and being tourist destinations rich in terms of experiential attributes, the likelihood to evoke an emotional response is even greater (Otto \& Ritchie, 1996). Places also help to predict and develop strong relationships in people (Hidalgo \& Hernández 2001; Williams \& Vaske 2003; Yuksel, Yuksel \& Bilim, 2010). As noted previously, consumer affective experiences have the power to influence their attachments to targets prominently featured during these experiences (Gross \& Brown, 2006; Hammitt et al., 2009; Hidalgo \& Hernández, 2001; Orth et al., 2010). The relationship between these affective experiences and activities strengthens visitors' place attachment (Gross \& Brown, 2008) and, similarly, consumers "connect" emotionally with a winery and its brand (Nowak \& Newton, 2006). To Kyle \& Chick (2007), emotional and symbolic meanings are antecedents of place identity, whereas functional meanings are antecedents of place dependence. Consequently, the sixth hypothesis is proposed:

\section{H6: Destination emotions are a positive and significant antecedent of place attachment in the Porto wine cellars}

From the prior contributions various authors also point out emotions as important precursors and an antecedent to tourist behavioural intentions (e.g. Grappi \& Montanari, 2011; Jang \& Namkung, 2009; Lee \& Shen, 2013; Yuksel \& Akgul, 2007). Previous studies (Bigné, Andrew \& Gnoth (2005); Grappi \& Montanari (2011); Han \& Jeong (2013); Yuksel \& Akgul (2007), established a positive path between positive emotions, satisfaction and behavioural intentions and adding to that, emotions seems to influence behavioural intentions (Baker \& Crompton, 2000; Faullant, Matzler \& Mooradian, 2011; Prayag, Osany \& Odeh (2013); White \& Scandale, 2005). White (2002) concluded that emotions are the strongest predictor of visitation intention, as well as the interaction between emotions and cognitive destination attributes.

Bigné \& Andrew (2004) have studied the emotions due to the impact that they have on decisionmaking of the visitors, which help to understand the tourist behaviour. Emotions result of hedonic consumption experiences, especially in the context of tourism, where expectations of pleasure motivate to travel (Goossens, 2000). Hence, the seventh hypothesis is the following:

\section{H7: Destination emotions have a positive and significant effect on behavioural intentions to visit the Porto wine cellars}

Hall et al. (2000) points that all facets of the wine tourism scene, from the countryside of vineyards to wineries, are the main elements and an important factor to attract consumers. The scenery and open spaces are considered some of the key attributes of a wine region, and they can be an incentive to visit the region (Getz, 1999). Thus, a visit to a wine region is generally enhanced by the "the attributes of a grape wine region" (Hall et al., 2000, p. 4), described as winescape (Peters, 1997). Charters \& AliKnight (2002) highlight the fact that wine regions tend to be beautiful places, and the vineyards themselves are visually attractive. Likewise, and following the concept of tourist terroir and wine, the experience gained through visits, has, for some tourist, a strong influence on the behavioural intention to visit a wine region (Sparks, 2007).

The past experience and the degree of satisfaction from these experiences also affect the choice of destinations and attractions visits (Yuan et al.,2008). Based on this background, the eighth hypothesis is:

H8: Place attachment has a positive and significant effect on behavioural intentions to visit the Porto wine cellars 
Overall, the present hypothesized conceptual model (Figure 1) demonstrating the intersection and combined use of these constructs, in order to measure their role. We therefore hypothesize that:

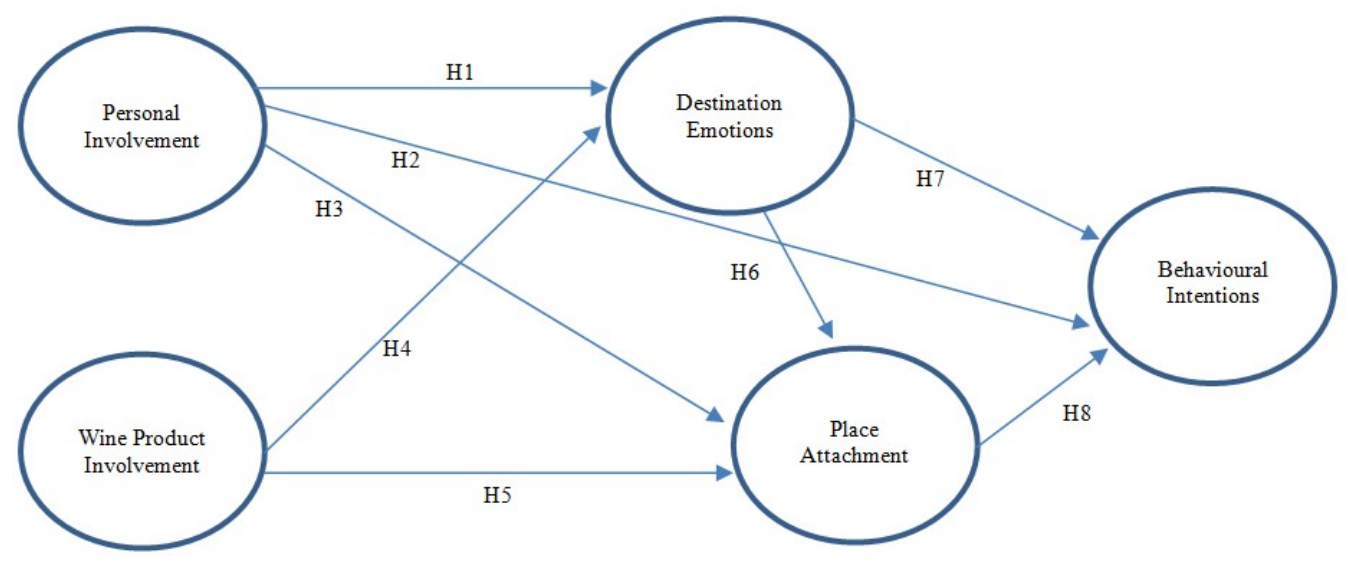

Figure I. The hypothesized conceptual model of the wine tourist behaviour

\section{Methodology}

\subsection{Sample design and data collection}

Data was collected from national and international wine tourists older than age 18 visiting the four Porto wine cellars (Ramos Pinto, Graham's, Taylor's and Croft), and were considered as the target study population, taking into account independent samples of similar and comparable population. The top five nationalities were: English, Spanish, French, Portuguese and German. In order to achieve a considerable sample size data was collected at the end of the visits between late August and early September 2015, as it coincides with the period that exhibits a greater flow of tourists to this destination. First, a pre-test was conducted with 40 respondents, to analyze and verify the consistency and reliability of the data collection instrument. The choice of a self-administrated questionnaire (one-to-one site surveys) as the data collection method was due to higher precision and have higher response rates and more complete answers, and the advantage of being more "user friendly" (Veal, 1992). A total of 918 self-administrated questionnaires were conducted and were considered for data analysis. The final sample size consisted of 918 complete questionnaires.

\subsection{Research instrument and questionnaire development}

The questionnaire consisted of three parts including four sections and was designed as the main instrument. Part 1 measured visiting Porto wine cellars included first section: measured destination emotions of the wine tourist; second section: measured personal involvement, consumer involvement profile and wine product involvement of the wine tourist; third section: measured place attachment with Porto wine cellars and fourth section: measured behavioural intentions to visit the Porto wine cellars. Part 2 measured general information about the visit to the Porto wine cellars. Part 3 measured general information about the personal demographics of the wine tourist.

Data collection was performed using the interceptive self-administered questionnaire, all personally conducted by the researcher, directly on tablets as a way to have more field-control over the collection and to improve response reliability. All items of the constructs scales selected were measured on a seven-point Likert scale. The final questionnaire was multilingual: English, Spanish, French, Portuguese and German, and was applied to 918 wine tourists, between August $24^{\text {th }}$ and September $5^{\text {th }}, 2015$, after the visits, in four Porto wine cellars, namely: Ramos Pinto, Graham's, Taylor's and Croft.

\subsection{Data analysis method}

An initial first approach to statistical analysis was performed using IBM.SPSS Statistics (version.22) software for in the descriptive statistical analysis.

The approach to multivariate analysis was performed using the SEM generalized modeling technique, in the descriptive phase of the quantitative analysis, the estimated with the empirical data was done by partial least squares (PLS) path modeling method (Vinzi, Trinchera \& Amato, 2010) and was applied using the SmartPLS V.3 software application (Ringle, Wende \& Becker, 2015), as it is the most suitable for this study 
because of its restrains as pointed by Hair, Ringle \& Sarstedt (2011) and Ringle, Sarstedt \& Straub (2012) Following the recommendations of Hair et al. (2014,) PLS should be used when there's a high number of missing values (in this case $12.3 \%$ of the sample) the existence of non-normal distributed data and nonhomogeneous variances between constructs variables. The large numbers of indicators to measure constructs (66 items in total), and the evaluation of the tested model. Also the PLS SEM approach is the most indicated method for testing an exploratory model (Hair et al, 2017), that is still under evaluation, as it is the case. The econometric model SEM used in marketing research presents a number of advantages and benefits such as the reliability of the measures, the use of multiple items buildings, easier measurement tests and even methods to assess construct validity (Kline, 2005; Iacobucci, 2010; Bagozzi \& Yi, 2012). Based on these assumptions argued above, a greater acceptance of the PLS appears to be accurate.

\section{Results}

The results of the descriptive statistical analysis were based on the respondents profile according to their socio-demographic information, as shown in Table I.

Table I. Socio-demographic profile of the sample respondents

\begin{tabular}{|c|c|c|c|c|}
\hline $\begin{array}{c}\text { Gender } \\
(\mathrm{N}=914)\end{array}$ & $\operatorname{Age}(\mathrm{N}=912)$ & $\begin{array}{c}\text { Education level }(\mathrm{N}= \\
914)\end{array}$ & $\begin{array}{c}\text { Country of } \\
\text { origin } \\
(N=916)\end{array}$ & $\begin{array}{c}\text { Job } \\
(\mathrm{N}=918)\end{array}$ \\
\hline & & & & $\begin{array}{l}\text { Businessman/ } \\
\text { manager }(12.6 \%)\end{array}$ \\
\hline & 18 years old $(2 \%)$ & & Portugal (2.6\%) & Freelancer/self-employed (16.4\%) \\
\hline & $\begin{array}{l}19-30 \text { years old } \\
(17.2 \%)\end{array}$ & $\begin{array}{l}\text { Less than high school } \\
\text { graduate }(3.4 \%)\end{array}$ & Spain $(10.8 \%)$ & $\begin{array}{lc}\text { Middle/ } & \text { senior } \\
\text { management }(23.7 \%)\end{array}$ \\
\hline $\begin{array}{l}\text { Male } \\
(51 \%)\end{array}$ & $\begin{array}{l}31-40 \text { years old } \\
(26.5 \%)\end{array}$ & $\begin{array}{l}\text { High school graduate } \\
(22.9 \%)\end{array}$ & France $(24.5 \%)$ & Civil servant $(16.7 \%)$ \\
\hline Female & 41-50 years old & & Germany $(7.2 \%)$ & Worker $(13.2 \%)$ \\
\hline \multirow[t]{6}{*}{$(49 \%)$} & $(26.8 \%)$ & $\operatorname{egree}(30.23$ & & \\
\hline & $51-60$ years & Lasters deoree $(283$ & United Kingdom & Pensioner/retired (4.6\%) \\
\hline & $(20.9 \%)$ & 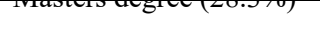 & $(12.2 \%)$ & \\
\hline & $\begin{array}{l}61-70 \text { years old } \\
(7.5 \%)\end{array}$ & Doctorate degree $(9.2 \%)$ & Brazil $(3.9 \%)$ & Domestic/unemployed (1.9\%) \\
\hline & $\begin{array}{l}\text { More than } 70 \text { years } \\
\text { old }(0.9 \%)\end{array}$ & & $\begin{array}{l}\text { Other countries } \\
(27.8 \%)\end{array}$ & Student $(3.9 \%)$ \\
\hline & & & & Other $(7 \%)$ \\
\hline
\end{tabular}

In the bootstrap analysis most relationships are statistically significant at a $99.9 \%$ level. In total, Table II indicates the Cronbach's Alpha and composite reliability values. These are above the critical values of 0.7 (Hair et al., 1998). All Cronbach's Alpha and the Composite reliability values are greater than 0.8, thus demonstrating high internal consistency.

In the validity analysis of the model, the values of the latent variables range from 0.53 (PI) to 0.85 (PA), whereby the AVE (Average Variance Extracted) of all constructs in analysis presents positive variances, indicating a good convergent validity (see Table II). Figure II provides details of the parameter estimates of the path model and $R^{2}$, the central dependent variables of the model are the ones that best explain variances, particularly the PA (0.72) and DE (0.70).

Thus, the $R^{2}$ values of these two endogenous or dependent variables are extremely positive. The dependent variable of $\mathrm{BI}$ still shows a $R^{2}$ value very close to the value of $0.5(0.49)$. The $Q^{2}$ predictive relevance is relevant to all endogenous constructs (Table II), PA has the highest $Q^{2}$ predictive relevance (0.61), after DE (0.38) and, at last, BI with 0.26.

Considering the IPMA analysis path model (Table II), the performance of PI (94), WPI (88), DE (94) and PA (93) are very close to the maximum value of 100 (Hair et al., 2014), indicating excellent performance of each on these three latent variables. 


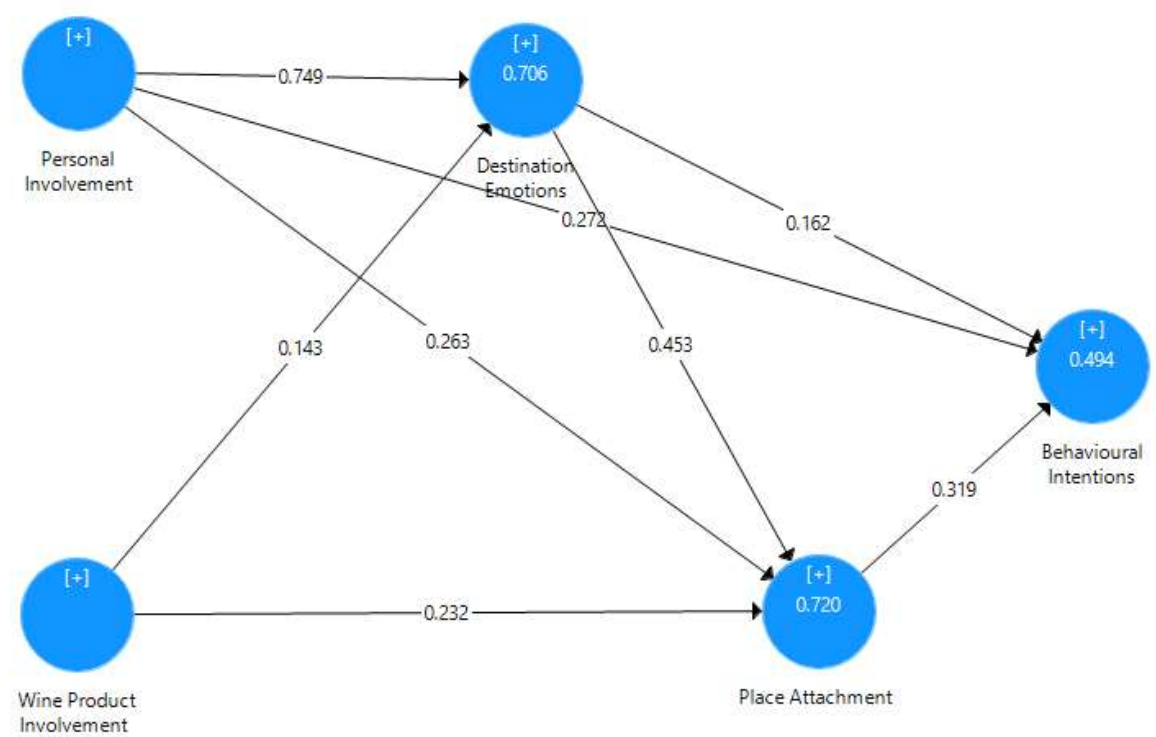

Table II. PLS multivariate analysis results

\begin{tabular}{|c|c|c|c|c|c|c|}
\hline Constructs & $\begin{array}{l}\text { Composite } \\
\text { Reliability }\end{array}$ & $\begin{array}{c}\text { Cronbach's } \\
\text { Alpha }\end{array}$ & $\boldsymbol{R}^{2}$ & AVE & $Q^{2}$ & $\begin{array}{c}\text { IPMA } \\
\text { Performance }\end{array}$ \\
\hline Personal Involvement (PI) & 0.96 & 0.95 & ------ & 0.53 & ------ & 94.694 \\
\hline Wine Product Involvement (WPI) & 0.93 & 0.92 & ------ & 0.64 & ------ & 88.212 \\
\hline Destination Emotions (DE) & 0.97 & 0.97 & 0.706 & 0.62 & 0.386 & 94.885 \\
\hline Place Attachment (PA) & 0.98 & 0.98 & 0.702 & 0.85 & 0.611 & 93.371 \\
\hline Behavioural Intentions (BI) & 0.87 & 0.81 & 0.494 & 0.62 & 0.263 & 96.163 \\
\hline
\end{tabular}

\section{Discussion and conclusions}

This study provided evidence that involvement, destination emotions (DE) and place attachment (PA) are positively related to the behavioural intentions (BI) of the wine tourist. A synergetic effect between the proposed constructs allow for a more holistic view of wine tourist behaviour. This enables an understanding how tourists are involved in the wine cellar's visits and the specific dynamics of the wine tourist behaviour.

All formulated hypotheses where statistically confirmed. However the strength of the different relationships in the structural model varies according the different construct combination. The relationship between personal involvement (PI) and destination emotions (DE) (H1) is the strongest relationship found on the structural model (path $.749 ; t$ 18.541). The result corroborates the findings of recent studies (Gao et al. 2013; Loureiro, Almeida \& Rita, 2013; Soscia, 2013) establishing that the personal involvement also determines the emotions generated by the visits. PI combined with the wine product involvement (WPI), determines a $R^{2}$ of .706 in the DE. This implies that an increase in these two constructs allows for stronger intentions to (re)visit. Also the combined effects (both directly and indirectly) between PI together with WPI and DE determine significantly the place attachment that the tourist feel $\left(R^{2}\right.$ of .720$)$. This makes the personal involvement (PI) the most significant independent construct.

The DE relationship with PA (H6) is the second strongest relationship found in the model (path .453; $t$ 5.630). Our results are confirmed in the context of the visits to the Porto wine cellars. Moreover DE proves to be the second most relevant construct. The combined effects between these 4 constructs (PI, WPI, DE and PA) have a lower determination power of around $50 \%\left(R^{2}\right.$ of .494$)$ in the behavioural intentions. This is may be explained by the fact that as the data was collected after the visits, it may be expected that their intentions (to visit or revisit) might decrease. The H6 provides empirical support for the practical discussion on the place attachment in wine tourism thus corroborating the few studies that suggested that DE can be a predictor of place attachment (Farber \& Hall, 2007; Giuliani \& Feldman, 1993; Kyle \& Chick, 2007; Manzo, 2003). 
The result indicate that when the destination (Porto wine cellars) creates strong and positive emotions in the wine tourist, the attachment (identity and dependence) that the wine tourist develop upon the visit will be consequently higher. The strength of the relationship of place attachment with behavioural intentions is much higher than the destination emotions. Therefore, it is understood that, for the wine tourist, the strong attachment to the cellars (path .319) and the place where they are located seems to be more determinant than the emotions created in the visit to the cellars (path .162).

The relationship between PA and BI (H8) is the third strongest relationship (path $.319 ; t 4.498$ ). Thus, it can suppose that PA presents himself as the third most relevant construct. The result corroborates the findings of other relevant studies ( Hall et al., 2000; Getz, 1999; Mazaheri, Richard \& Laroche, 2012; Sparks, 2007). It also contributes to the synergetic effect along with the other constructs (PI, WPI, DE and PA) on the BI. Porto wine cellars provides an attachment in consonance with the specific identity and dependence characteristics of its place, appreciated by wine tourists during their visits, which then reflect a greater or lesser in their behaviour (BI).

The PI relationship with BI (H2) is the fourth strongest relationship (path $.272 ; t 3.099)$. The result is in line with what is pointed out by Gursoy \& Gavcar (2003); Kyle et al. (2004); Sparks (2007); Prayag \& Ryan (2012) and Prebensen et al. (2013). This implies that an involvement which is, for example, beneficial, valuable and significant, maximizes the personal involvement and consequently the behavioural intentions of the wine tourists in their visits to Porto wine cellars.

The relationship between PI and PA (H3) is the fifth strongest relationship (path $.263 ; t 3.488$ ). The result confirms the significant and direct path between these constructs, but particularly in the Porto wine cellars.

The relationship between WPI and PA (H5) is the sixth strongest relationship (path $.232 ; t 4.811$ ). There are several of recent research results pointing to a relationship between product involvement and place attachment in other sectors (Alant \& Bruwer, 2004; Bruwer \& Alant, 2009; Getz \& Brown, 2006b; Roberts \& Sparks, 2006; Yuan et al., 2005). The result of H5 reinforces particularly the findings of Gross \& Brown (2008) that confirmed that wine product involvement has a direct effect on place attachment. This finding also demonstrated that the specificity of the Porto wine cellars allow, through the wine involvement, an attachment related to the identity and dependence perceived during the visits. The results also revealed that the wine product involvement imply a greater connection with the attachment to the cellars (path .232) compared with the emotions created by the cellars (path .143). This can be explained by the fact that involvement is related to the wine intrinsic attributes. Porto wine is a very specific product with key features (Raham \& Reynolds, 2015), that are inherent and associate directly to the touristic terroir (Hall \& Mitchell, 2002) and to the nature of the product (Veale \& Quester, 2009). To add to this view, also the authenticity, heritage value and iconicity (Ram, Björk \& Weidenfeld, 2016), such as the appeal of wine regions based on "difference of place" (Bruwer, 2003) (considering the Porto wine cellars in this study) also contribute to strengthen this connection between the wine product involvement and the place attachment.

Our study demonstrates that the relationship between destination emotions and behavioural intentions (H7) and is one of two least strong relationships (path .162; t 2.084) on the structural model. The result corroborates the findings of Baker \& Crompton (2000); Bigné, Andrew \& Gnoth (2005); Faullant, Matzler \& Mooradian (2011); Grappi \& Montanari (2011); Han \& Jeong (2013); Jang \& Namkung (2009); Lee \& Shen (2013); Prayag, Osany \& Odeh (2013); White (2002); White \& Scandale (2005) and Yuksel \& Yuksel (2007) in different fields. Our results adding this positive and significant effect between DE and BI (H7) specifically in the Porto wine cellars field.

The relationship between wine product involvement and destination emotions (H4), although significant and positively proven, is the least strong relationship (path $.143 ; t 3.656$ ). There is no previous study examining these relationship in touristic and wine context, although there are recent research that supports this (Ali-Knight \& Carlsen, 2003; Barber, Ismail \& Dodd, 2008; Bruwer \& Alant, 2009; Charters \& Pettigrew, 2005; Famularo, Bruwer \& Li, 2010; Keonig-Lewis \& Palmer, 2008; Mora \& Moscarola, 2010; Sparks, 2007). Given this empirical evidence, the Porto wine involvement explains the degree of destination emotions with the visits, taking into account the other Porto wine related-activities, Porto wine tastings as well as the prior knowledge of Porto wine.

The selected scales have been validated in prior on their studies, such as consumer behaviour, leisure, marketing and tourism contexts. Only a few items needed to be adapted to the wine tourism context, and some other items were excluded due to redundancy amongst them. The validation of the structural model was confirmed by multivariate statistical analysis with SEM using the PLS (version.3), concluding the relevance of the model by the use of the PLS-SEM.

\section{Practical implications}


The findings may offer important implications for managing wine destination services, such as positioning and reinforce the consolidation of destination branding of the Porto wine cellars. The analysis of the results suggests new implications on behavioural intentions of the wine tourist. The findings are particularly valuable to wine tourism destination marketers with direct or indirect responsibility to develop strategic planning in order to attract and retain the wine tourists to visit their activities and wine attractions included in the visits.

Some implications concern the management of Porto wine cellars. In this perspective, involvement, destination emotions and place attachment should be considered key drivers for wine cellars managers since they evoke and conduct a positive wine tourist travel behaviour. The Porto wine cellars managers should develop of a more strategic and integrated way the attachment inherent to cellars (including the identity and dependence), assuming that, through of this study results, to wine tourists the place attachment seems to be more determinant in the visit to the cellars.

Both managers and wine tourist guides should further develop their system of guided tours, which would allow them to maintain and increase the wine tourist involvement with the Porto wine cellars.

The wine involvement and the Porto wine tastings explain the destination emotions and place attachment of wine tourists, and it is essential there are different types of tastings, to understand the perceived importance of wine tasting, according to the wine knowledge level and their respective tasting techniques. Accordingly, it will be possible to create long term relationships with cellars and similar wine-related lifestyles.

Furthermore, the degree of interest, knowledge and curiosity during visits to Porto wine cellars ranges between wine tourism curious and wine tourism lover, may enhance the targeting of the wine tourists on guided tours.

\section{Research limitations}

As research limitations, the reduced data collection period (between August 24 and September 5, 2015) does not allowed generalize results to a semester, year or season, and the data collection only occurred in a unique geographic point (Porto wine cellars), and in four cellars (Taylor's, Croft, Ramos Pinto and Graham's), in the total of the main seven cellars, which can limit the generalization to other contexts, due to budget constraint because this work is an academic study and was not funded.

Another limitation is related to the self-reported questionnaires, due to the environment in which wine tourists filled out the questionnaires, after their visits, in different available areas of the cellars, but we could not do it in another location. Moreover, the missing values $(12.3 \%)$ also represent a caveat, due to some incomplete and unanswered answers that were not considered for data analysis. A non-probabilistic convenience sample, although the quite large $(\mathrm{n}=918)$ limits the research to some extent.

\section{Suggestions for future research}

The limitation regarding the identified reduced time period for data collection allows suggest a longitudinal evaluation of consumer behaviour in wine tourism not only in Porto wine cellars, but also to other WTD contexts, as wine hotels, other type of wine cellars such as the Champagne wine cellars, wineries or wine estates. Also it would be useful evaluate the effect of socio-demographic moderating variables (age, education level, country of origin, job), to test their role and impact on data interpretation for wine tourist segmentation. Considering that combined effects between four constructs (PI, WPI, DE and PA) have a lower determination power in the behavioural intentions, it is suggested measure these constructs before the visits, during decision making, in order to analyze and evaluate if behavioural intentions of the wine tourists increases in the visits to Porto wine cellars.

\section{References}

Alant, K., \& Bruwer, J. (2004). Wine Tourism Behaviour in the Context of a Motivational Framework for Wine Regions and Cellar Doors. Journal of Wine Research, 15(1), 27-37.

Ali-Knight, J., \& Carlsen, J. (2003). An exploration of the use of "extraordinary" experiences in wine tourism. In Lockshin, L. \& Rungie, C. (Eds.), Proceedings of the International Colloquium in Wine Marketing, Wine Marketing Group, University of South Australia, Adelaide.

Altman, I., \& Low. S. M. (1992). Place Attachment. New York: Plenum.

Baker, D. A., \& Crompton, J. L. (2000). Quality, satisfaction and behavioral intentions. Annals of Tourism Research, 27(3), 785-804.

Bagozzi, R., \& Yi, Y. (2012). Specification, evaluation, and interpretation of structural equation models. Journal of the Academy of Marketing Science, 40(1), 8-34. 
Bagozzi, R., Gopinath, M., \& Nyer, P. U. (1999). The Role of Emotions in Marketing. Journal of the Academy of Marketing Science, 27(2), 184-206.

Bigné, J. E., \& Andreu, L. (2004). Emotions in Segmentation - An empirical study. Annals of Tourism Research, 3, 682696.

Bigné, J. E., Andreu, L., \& J. Gnoth, J. (2005). The Theme Park Experience: An Analysis of Pleasure, Arousal and Satisfaction. Tourism Management, 26(6), 833-844.

Brown, G., \& D. Getz (2005). Linking wine preferences to the choice of wine tourism destinations. Journal of Travel Research, 43(3), 266-276.

Bruwer, J. (2003). South African Wine Routes: Some Perspectives on the Wine Tourism Industry's Structural Dimensions and Wine Tourism Product. Tourism management, 24(4), 423-435.

Bruwer, J., \& Alant, K. (2009). The hedonic nature of wine tourism consumption: an experiential view. International Journal of Wine Business Research, 21(3), 235-257.

Bruwer, J., \& Reilly, M. (2006). The power of word-of-mouth communication as an information source for winery cellar door visitors. Australian \& New Zealand Wine Industry Journal, 21(3), 43-52.

Charters, S., \& Ali-Knight, J. (2002). Who is the wine tourist? Tourism Management, 23(3), 311-319.

Chiu, Y. T. H., Lee, W. I., \& Chen, T. H. (2014). Environmentally responsible behavior in ecotourism: Antecedents and implications. Tourism Management, 40, 321-329.

Farber, M. E., \& Hall, T. E. (2007). Extraordinary Experiences along the Dalton Highway in Alaska. Journal of Leisure Research, 39(2), 248-70.

Famularo, B., Bruwer, J., \& Li, E. (2010). Region of origin as choice factor: wine knowledge and wine tourism involvement influence. International Journal of Wine Business Research, 22(4), 362-85.

Faullant, R., Matzler, K., \& Mooradian, T. A. (2011). Personality, basic emotions, and satisfaction: Primary emotions in the mountaineering experience. Tourism Management, 32(6), 1423-1430.

Ferrarini, R., Carbognin., C., Casarotti, E. M., Nicolis, E., \& Nencini, A. (2010). The emotional response to wine consumption. Food Quality and Preference, 21, 720-725.

Gao, J., Ma, J., Scott, N., \& Ding, P. (2013). Customer delight from theme park experiences: The antecedents of delight based on cognitive appraisal theory. Annals of Tourism Research, 42, 359-381.

Getz, D., \& Brown, G. (2006). Critical success factors for wine tourism regions: A demand analysis. Tourism Management, 27(1), 146-158.

Getz, D., \& Brown, G. (2006b). Critical Success Factors for Wine Tourism Regions: a Demand Analysis. Tourism Management, 27, 146-158.

Getz, D. (1999). Wine tourism: Global overview and perspectives on its development. In R. Dowling, \& J. Carlsen (Eds.), Wine tourism perfect partners. Proceedings of the first Australian wine tourism conference (pp. 13-33). Margaret River, Australia, May 1998, Canberra: Bureau of Tourism Research.

Grappi, S., \& Montanari, F. (2011). The role of social identification and hedonism in affecting tourist re patronizing behaviors: The case of an Italian festival. Tourism Management, 32(5), 1128-1140.

Gross, M. J., Brien, C., \& Brown, G. (2008). Examining the dimensions of a lifestyle tourism destination. International Journal of Culture, Tourism and Hospitality Research, 2(1), 44-66.

Gross, M. J., \& Brown, G. (2008). An empirical structural model of tourists and places: progressing involvement and place attachment into tourism. Tourism Management, 29(6), 1141-1151.

Gross, M. J., \& Brown, G. (2006). Tourist experience in a lifestyle destination setting: the roles of involvement and place attachment. Journal of Business Research, 59(6), 696-700.

Gu, H., \& Ryan, C. (2008). Place attachment, identity and community impacts of tourism - the case of Beijing hutong. Tourism Management, 29, 637-647.

Gursoy, D., \& Gavcar, E. (2003). International leisure tourists' involvement profile. Annals of Tourism Research, 30(4), 906-926.

Hair, J. F., Sarstedt, M., Hult, T., \& Ringle, (2017) A Primer on partial lest Squares strucutural equation modeling (PLSSEM), $2^{\text {nd }}$ Edition, Sage.

Hair, J. F., Sarstedt, M., Hopkins, L., \& Kuppelwieser, V. G. (2014). Partial least squares structural equation modeling (PLS-SEM): An emerging tool in business research. European Business Review, 26(2), 106-121.

Hair, J. F., Ringle, C. M., \& Sarstedt, M. (2011). PLS-SEM: Indeed a Silver Bullet. Journal of Marketing Theory and Practice, 19(2), 139-152.

Hair, J. F., Jr., Black, W. C., Babin, B. J., \& Anderson, R. E. (2010). Multivariate data analysis. New Jersey: Pearson Prentice Hall.

Hair, J. F., Anderson, R., Tatham, R., \& Black, W. (1998). Multivariate Data Analysis (5th Ed.). London: Prentice-Hall.

Hall, C. M., \& Mitchell, R. (2002). The touristic terroir of New Zealand wine: the importance of region in the wine tourism experience. In Montanari, A. (Ed.), Food and environment: geographies of taste (pp. 69-91). Rome: Societa Geografica Italiana. 
Hall, C. M., Johnson, G., \& Mitchell, R. (2000). Wine Tourism and Regional Development. In Hall, C. M., Sharples, L., Cambourne, B., \& Macionis, N. (Eds.), Wine Tourism Around the World: Development, Management and Markets (pp. 196-225). Oxford: Elsevier Science.

Hall, C. M., L. Sharples, Cambourne, B., \& Macionis, N. (2000). Wine Tourism around the World: Development, Management and Markets. Oxford: Elsevier Butterworth-Heinemann.

Hall, C. M., Johnson, G., Cambourne, B., Macionis, N., Mithcell, R., \& Sharples, L. (2000). Wine tourism: an introduction. In Hall, C. M., Sharples, L., Cambourne, B., \& Macionis, N. (Eds.), Wine tourism around the world (pp. 1-23). Oxford: Butterworth-Heinemann.

Hammitt, W. E., Kyle, G. T., \& Oh, C. O. (2009). Comparison of place bonding models in recreation resource management. Journal of Leisure Research, 41(1), 57-72.

Han, H., \& Jeong, C. (2013). Multi-dimensions of patrons' emotional experiences in upscale restaurants and their role in loyalty formation: Emotion scale improvement. International Journal of Hospitality Management, 32, 59-70.

Hidalgo, M. C., \& Hernández, B. (2001). Place attachment: conceptual and empirical questions. Journal of Environmental Psychology, 21(3), 273-281.

Hightower, R., Brady, M. K., \& Baker, T. L (2002). Investigating the role of physical environment in hedonic service consumption and exploratory study of sport events. Journal of Business Research, 55, 697-707.

Hou, J., Lin, C., \& Morais, D. B. (2005). Antecedents of Attachment to a Cultural Tourism Destination: The Case of Hakka and Non-Hakka Taiwanese Visitors to Pei-Pu, Taiwan. Journal of Travel Research, 44(4), 221-33.

Iacobucci, D. (2010). Structural equations modeling: Fit Indices, sample size, and advanced topics. Journal of Consumer Psychology, 20, 90-98.

Jang, S., \& Y, Namkung. (2009). Perceived Quality, Emotions, and Behavioral Intentions: Application of an Extended Mehrabian-Russell Model to Restaurants. Journal of Business Research, 62(4), 451-460.

Keonig-Lewis, N., \& Palmer, A. (2008). Experiential values over time: a comparison of measure of satisfaction and emotion. Journal of Marketing Management, 24(1/2), 69-85.

Kline, R. B. (2005). Principles and Practice of Structural Equation Modeling. New York, NY: Guilford.

Kyle, G., Bricker, K., Graefe, A., \& Wickham, T. (2004). An examination of recreationists' relationships with activities and settings. Leisure Sciences, 26(2), 123-142.

Kyle, G., Graefe, A., Manning, R., \& Bacon, J. (2004). Effects of place attachment on users' perceptions of social and environmental conditions in a natural setting. Journal of Environmental Psychology, 24(2), 213-225.

Kyle, G., Graefe, A., Manning, R., \& Bacon, J. (2003). An examination of the relationships between leisure activity involvement and place attachment among hikers along the Appalachian Trail. Journal of Leisure Research, $35(3), 249-257$.

Kyle, G., \& Chick, G. (2007). The social construction of a sense of place. Leisure Sciences, 29, 209-227.

Lee, T. H., \& Shen, Y. L (2013). The influence of leisure involvement and place attachment on destination loyalty: Evidence from recreationists walking their dogs in urban parks. Journal of Environmental Psychology, 33, 7685.

Lee, J., Graefe, A., \& Burns, R. (2007). Examining the antecedents of destination loyalty in a forest setting. Leisure Sciences, 29, 463-481.

Lee, Y. K., Lee, C. K., Lee, S. K., \& Babin, B. J. (2008). Festivalscapes and patrons' emotions, satisfaction and loyalty. Journal of Business Research, 61, 56-64.

Liang, Y., Illum, S. F., \& Cole, S. T. (2008). Benefits received and behavioural intentions of festival visitors in relation to distance travelled and their origins. International Journal of Event Management Research, 4(1), 12-23.

Loureiro, S. M. C., Almeida, M., \& Rita, P. (2013). The effect of atmospheric cues and involvement on pleasure and relaxation: the spa hotel context. International Journal of Hospitality Management, 35, 35-43.

Low, S. M., \& Altman, I. (1992). Place attachment: A conceptual inquiry. Human Behavior \& Environment: Advances in Theory \& Research, 12, 1-12.

Machleit, K. A., \& Eroglu, S. A. (2000). Describing and Measuring Emotional Response to Shopping Experience. Journal of Business Research, 49(2), 101-111.

Manzo, L. C. (2003). Relationships to Non-residential Places: Towards a Reconceptualization of Attachment to Place. Journal of Environmental Psychology, 23(1), 47-61.

Mazaheri, E., Richard, M. O., \& Laroche, M. (2012). The role of emotions in online consumer behaviour: a comparison of search, experience, and credence services. Journal of Services Marketing, 26(7), 535-550.

Mora, P., \& Moscarola, J. (2010). Representations of the emotions associated with a wine purchasing or consumption experience. International Journal of Consumer Studies, 34, 674-683.

Mowen, A. J., Graefe, A. R., \& Virden, R. J. (1998). A typology of place attachment and activity involvement. Proceedings of the 1997 Northeastern Recreation Research Symposium.

Nyer, P. U. (1997). Modeling the cognitive antecedents of post-consumption emotions. Journal of Consumer Satisfaction, Dissatisfaction and Complaining Behavior, 10, 80-90.

Nowak, L. I., \& Newton, S. K. (2006). Using the tasting room experience to create loyal customers. International Journal of Wine Marketing, 18(3), 157-65. 
Otto, J. E., \& Ritchie, B. R. (1996). The Service Experience in Tourism. Tourism Management, 17(3), 165-174.

Peters, G. L. (1997). American winescapes: The cultural landscapes of America's wine country. USA: Westview Press.

Prayag, G., Hosany, S., \& Odeh, K. (2013). The role of tourists' emotional experiences and satisfaction in understanding behavioral intentions. Journal of Destination Marketing \& Management, 2, 118-127.

Prayag, G., \& Ryan, C. (2012). Antecedents of tourists' loyalty to Mauritius: the role and influence of destination image, place attachment, personal involvement and satisfaction. Journal of Travel Research, 51(3), 342-356.

Prebensen, N. K., Woo, E., Chen, J. S., \& Uysal, M. (2013). Motivation and involvement as antecedents of the perceived value of the destination experience. Journal of Travel Research, 52(2), 253-264.

Rahman, I., \& Reynolds, D. (2015). Wine: Intrinsic attributes and consumers' drinking frequency, experience, and involvement. International Journal of Hospitality Management, 44(1), 1-11.

Ram, Y., Bjork, P., \& Weidenfeld, A. (2016). Authenticity and place attachment of major visitor attractions. Tourism Management, 52, 110-122.

Ravenscroft, N., \& van Westering, J. (2001). Wine tourism, culture and the everyday: a theoretical note. Tourism and Hospitality Research, 3(2), 149-62.

Richins, M. L. (1997). Measuring Emotions in Consumption Experience. Journal of Consumer Research, 24(9), 127146.

Ringle, C. M., Wende, S., \& Becker, J.-M. (2015). SmartPLS 3. Boenningstedt: SmartPLS GmbH. Retrieved from http://www.smartpls.com.

Ringle, C. M., Sarstedt, M., \& Straub, D. W. (2012). A critical look at the use of PLS-SEM in Mis Quarterly. MIS Quarterly, 36, iii-xiv.

Roberts, L., \& Sparks, B. (2006). Enhancing the Wine Tourism Experience: the Customers' Viewpoint. In Carlsen, J., \& Charters, S. (Eds.), Global Wine Tourism: Research, Management \& Marketing (pp. 47-55). UK \& USA: CAB International.

Santos, Ramos \& Almeida (2015). Consumer Behaviour in Wine Tourism: involvement, destination emotions and place attachment in the wine tourist behaviour during the Porto wine cellars visits context. $\mathrm{PhD}$ Thesis.

Santos, V., Ramos, P., \& Almeida, N. (2014). Consumer behaviour in tourism: a content analysis of the relationship between involvement and emotions. Journal of Tourism Research, 9(7), 1-29.

Soscia, I. (2013). Emotions and Consumption Behaviour. United Kingdom: Edward Elgar Pub.

Sparks, B. (2007). Planning a wine tourism vacation? Factors that help to predict tourist behavioural intentions. Tourism Management, 28(5), 1180-1192.

Veal, A. J. (1992). Research methods for leisure and tourism: A practical guide. London: Pitman.

Veale, R., \& Quester, P. (2009). Tasting quality: the roles of intrinsic and extrinsic cues. Asia Pacific Journal of Marketing and Logistics, 21(1), 195-207.

Vinzi, V., Trinchera, L., \& Amato, S. (2010). PLS Path Modeling: From Foundations to Recent Developments and Open Issues for Model Assessment and Improvement (pp. 47-82). In Vinzi, V., Chin, W., Henseler, J., \& Wang, H. (Eds.), Handbook of partial least squares: Concepts, methods and applications in marketing and related fields (pp. 655-690). Berlim: Springer.

Warzecha, C. A., \& Lime, D. W. (2001). Place Attachment in Canyonlands National Parks: Visitors' assessment offsetting attributes on the Colorado and Green Rivers. Journal of Park and Recreation Administration, 19(1), 59-78.

White, C. J., \& Scandale, S. (2005). The role of emotions in destination visitation intentions: A cross-cultural perspective. Journal of Hospitality \& Tourism Management, 12(1), 168-178.

White, C. J. (2002). Emotions, Gender and Destination Visitation Intentions. I Coloquio Predoctoral Europeo of Tourism and Leisure. ESADE-IMHI (Cornell-ESSEC). Retrieved July 7, 2015, from http://www.esade.es/cedit2003/cast/est papsen.htm.

Williams, D. R., Patterson, M. E., \& Roggenbuck, J. W. (1992). Beyond the Commodity Metaphor: Examining emotional and symbolic attachment to place. Leisure Sciences, 14, 29-46.

Williams, D. R., \& Vaske, J. J. (2003). The Measurement of Place Attachment: Validity and Generalizability of a Psychometric Approach. Forest Science, 49(6), 830-840.

Yeh, C. M. (2013). Tourism Involvement, Work Engagement and Job Satisfaction among Frontline Hotel Employees. Annals of Tourism Research, 10(10), 214-239.

Yuan, J., Cai, L. A., Morrison, A. M., \& Linton, S. (2008). A Model of Wine Tourist Behaviour: A Festival Approach. International Journal of Tourism Research, 10(2), 207-219.

Yuan, J., Jang, S., Cai, L., Morrison, A., \& Linton, S. (2006). Analysis of Motivational and Promotional Effects of a Wine Festival. In J. Carlsen and S. Charters (Eds.) Global Wine Tourism: Research Management and Marketing. London: CABI Publishing.

Yuan, J., Cai, L. A., Morrison, A. M., \& Linton, S. (2005). An Analysis of Wine Festival Attendees' Motivations: A Synergy of Wine, Travel and Special Events? Journal of Vacation Marketing, 11(1), 41-58.

Yuksel, A., \& Akgul, O. (2007). Postcards as affective image makers: An idle agent in destination marketing. Tourism Management, 28(3), 714-725. 
Yuksel, A., \& Yuksel, F. (2007). Shopping Risk Perceptions: Effects on Tourists' Emotions, Satisfaction and Expressed Loyalty Intentions. Tourism Management, 28(3), 703-713.

Zaichkowsky, J. L. (1985). Measuring the involvement construct. Journal of Consumer Research, 12(3), 341-352.Zhang, X. (2011). Research on the development of Wine Tourism Product based on the analysis of the wine tourist behavioral intentions. Artificial Intelligence, Management Science and Electronic Commerce (AIMSEC), 2011, $2^{\text {nd }}$ International Conference (pp. 1439-1442). Shanghai: AIMSEC.

Zhang, X. (2011). Research on the development of Wine Tourism Product based on the analysis of the wine tourist behavioral intentions. Artificial Intelligence, Management Science and Electronic Commerce (AIMSEC), 2011, 2nd International Conference (pp. 1439-1442). Shanghai: AIMSEC. 